\title{
Seismic stratigraphy of the Bill Bailey and Lousy Bank area: implications for subsidence history
}

\author{
K. VANNESTE, ${ }^{1}$ J.-P. HENRIET, ${ }^{1,2}$ J. POSEWANG ${ }^{3}$ \& F. THEILEN ${ }^{3}$ \\ ${ }^{1}$ Renard Centre of Marine Geology, University of Gent, Krijgslaan 281, B-9000 Gent, \\ Belgium \\ ${ }^{2}$ Present address: IFREMER, Département des Géosciences marines, 29280 Plouzané, \\ France \\ ${ }^{3}$ Institut für Geophysik, University of Kiel, Olshausenstraße 40-60, D-2300 Kiel, Germany
}

\begin{abstract}
The present study discusses some results of a reconnaissance seismic survey carried out in 1988 in the area around the prominent Bill Bailey and Lousy Banks, located SW of the Faeroe Islands. The area is thought to be part of the Rockall-Faeroe microcontinent, which was flooded by Palaeocene plateau basalts. The seafloor topography is largely due to the present-day organization of the basalt surface. Important structural features exhibited by this basement are sub-surface diverging reflectors and a major fault.

Sediment accumulation is confined to the basinal area where four unconformities were identified. The lower boundary corresponds to the well-known reflector R4 of the North Atlantic. The other unconformities are proposed to correlate with hiatuses at the beginning and end of the middle Miocene, and at the end of the Pliocene, respectively. The sediment units are briefly described by their upper and lower boundary, seismic facies and thickness variations. About the lithology, however, little is so far known. The sediments are deformed by intraformational faults and a diapir-like structure. Both deformational styles are probably related to temporary overpressurisation in fine-grained sediments, but resulting from different causes.

Stratal geometric patterns indicate that initially the subsidence of the basalt surface was rather uniform, but became non-uniform after the Eocene/Oligocene boundary, differentiating the two banks from the surrounding basin.
\end{abstract}

In May-June 1988 a reflection seismic survey was set up jointly by the Geophysical Institute of Kiel (Germany) and the Renard Centre of Marine Geology in Gent (Belgium). The aim was to investigate the sedimentary patterns on the flanks of the Iceland-Faeroe Ridge. The area southwest of the Faeroe Islands, marked by prominent seamounts, was involved in the investigations: six reconnaissance profiles were shot across the Bill Bailey and Lousy (or Outer Bailey) Banks. An airgun array totalling between 2.61 and 3.81 was used as acoustic source. The reflected signals were detected by a 24channel streamer with an active length of $600 \mathrm{~m}$. Only the analogue monitor recordings and the common-offset plots are presented here.

The Bill Bailey and Lousy Banks delimit the northern edge of the Rockall Trough. Together with the Faeroe Bank these banks link the Rockall Plateau in the SW with the Faeroe insular block in the NE. Their location is shown in Fig. 1, along with the available seismic lines.

Seismic (Bott et al. 1971, 1974; Casten 1973) and isotopic (Hald \& Waagstein 1983) evidence shows that the Faeroe Island block may be underlain by continental crust which probably extends beneath the Faeroe, Bill Bailey and Lousy Banks (e.g. Roberts et al. 1983), thus adjoining the Rockall microcontinent in a southwestward direction. This so-called Rockall-Faeroe microcontinent became isolated by two distinct extensional phases: the area was split from the main European continent by an early to mid Cretaceous rifting episode (Roberts 1975; Roberts et al. 1983) which created the Rockall Trough and the Faeroe-Shetland Channel. And in late Palaeocene times the RockallFaeroe microcontinent broke away from Greenland, giving way to the opening of the northern North Atlantic. This second extensional phase was accompanied by the massive subaerial extrusion of plateau basalts which flooded large parts of the microcontinent within a few million years. The presence of a thick pile of Palaeocene plateau basalts is well established on the Faeroe Islands, on the northern Rockall Plateau (Laughton et al. 1972; Roberts 1975) and in the area bounding the northern Rockall Trough 


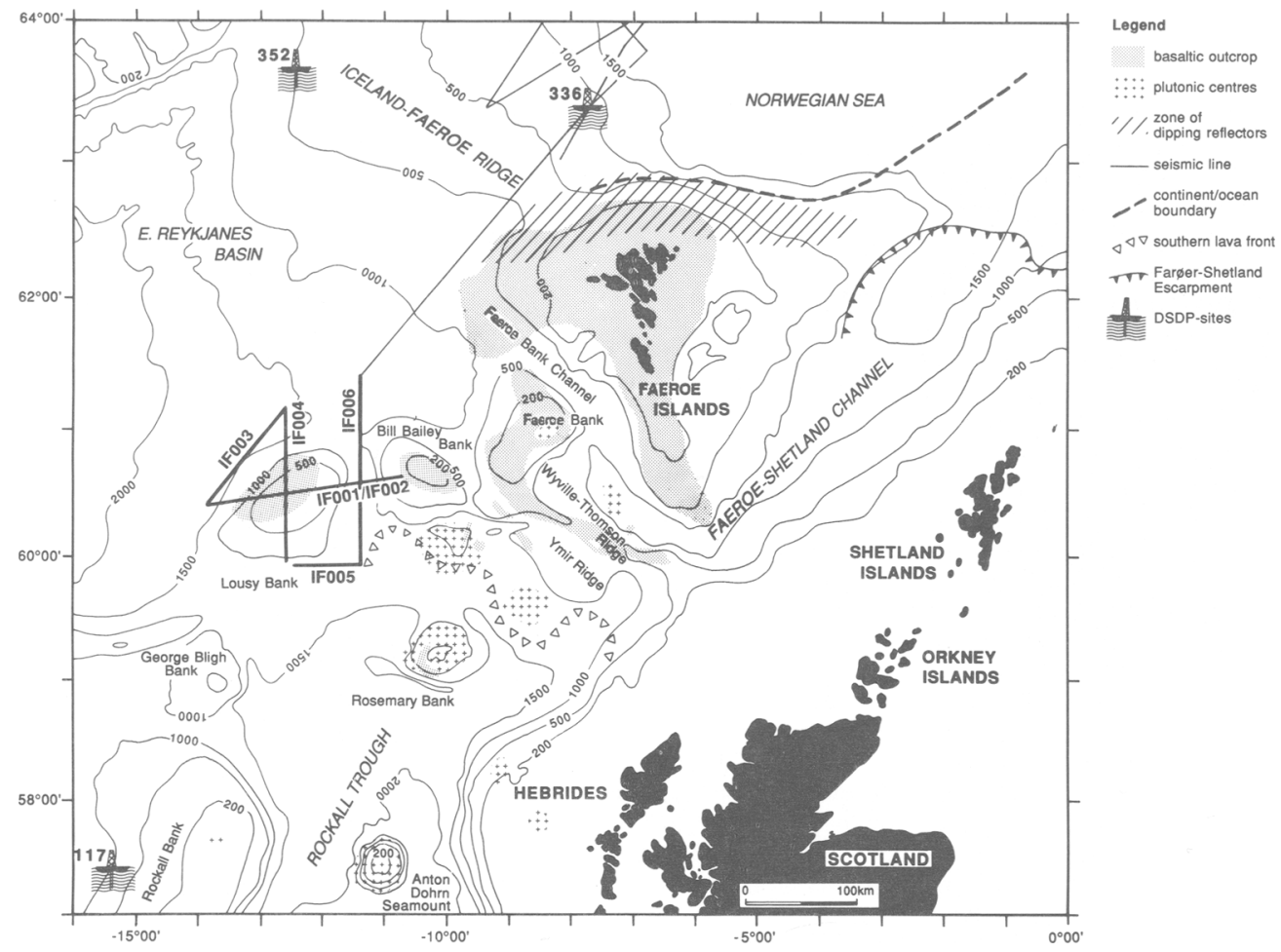

Fig. 1. Generalized bathymetric map of the area, compiling available seismic grid, basaltic outcrop (from Waagstein 1988), plutonic centres (after Roberts et al. 1983), zone of dipping reflectors (Andersen 1988), oceancontinent boundary (from Smythe 1983), the southern lava front (from Wood et al. 1988), together with relevant DSDP sites. Mercator projection at $60^{\circ} \mathrm{N}$.

(e.g. Roberts et al. 1983; Wood et al. 1987).

The edges of the microcontinent were identified on the northern margin of the Faeroe shelf by the recognition of oceanward dipping reflectors (Smythe 1983; Andersen 1988), but have not been detected along the northern flanks of the Bill Bailey and Lousy Banks up to now.

\section{Acoustic basement}

On all profiles (Figs 2-5) a strong acoustic basement reflector (labelled EE) can easily be identified. Mainly by virtue of its relatively rough topography and hyperbolic character - a reflection pattern commonly regarded as characteristic of basalt - it was interpreted as the top of the ubiquitous flood basalts.

As can be readily observed on lines IF001/ IF002 (Fig. 2), the organization of two banks and an intervening basin is already manifest at the level of the acoustic basement. In the narrow basin separating Bill Bailey Bank from Lousy Bank the acoustic basement appears at a depth of c. $2200 \mathrm{~ms}$ two-way travel time (TWT) below the bank crests, a pronounced downwarping which occurs without any major faulting. The pronounced basement relief is strongly reflected in the present-day seafloor topography, although over $1000 \mathrm{~ms}$ of sediments have accumulated between the banks. The crests of the two banks bear nearly no sediments and are flattened, which - according to Roberts et al. (1983) - could be due to 'subaerial erosion of an original volcanic landform'.

Underneath the basalt surface divergent reflectors can be observed beneath the northern and western flanks of Lousy Bank (line IF004, Fig. 3) and beneath the northern flank of Bill Bailey Bank. Due to the limited capacity of the acoustic source, however, these structures could not be very well elucidated. Roberts et al. (1983) observed similar 'outward'-dipping reflectors on 


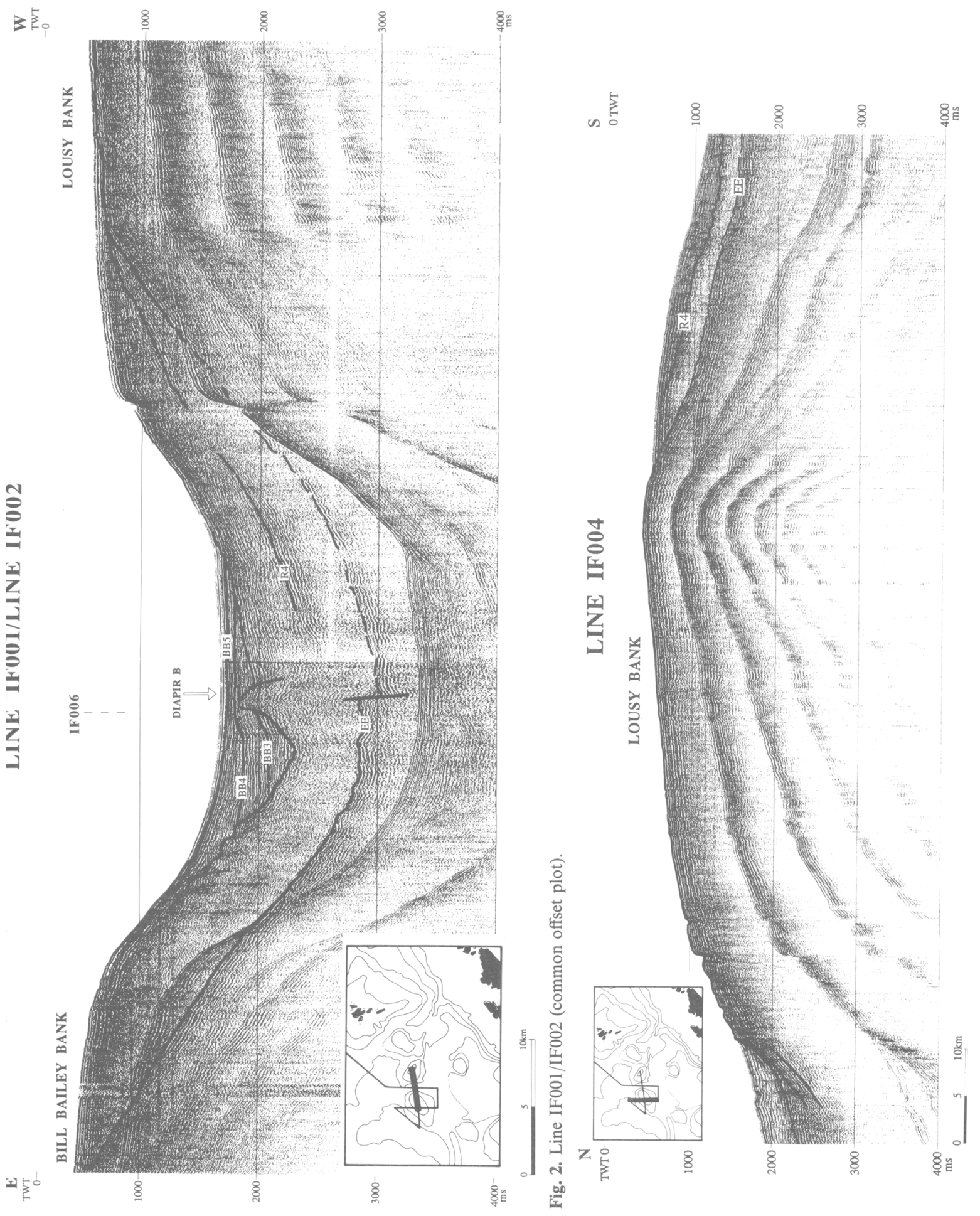




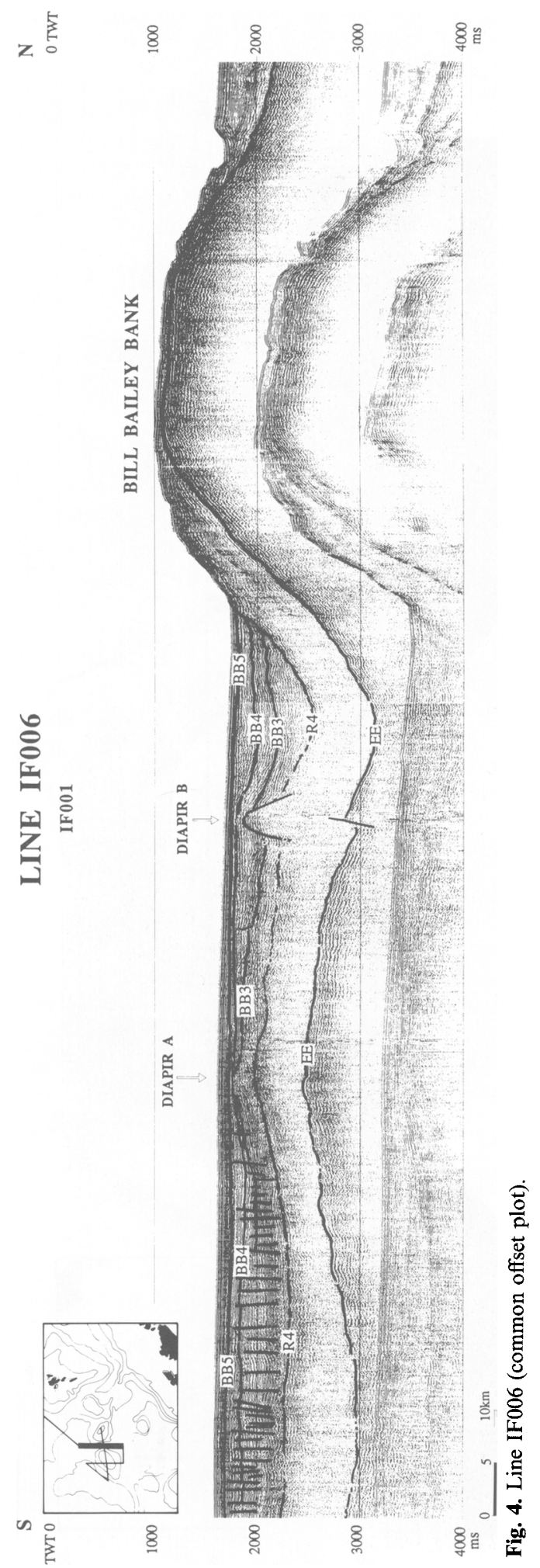


their seismic lines across the banks. They interpreted them as volcanic layering. It is possible that these diverging reflectors correspond to the oceanward-dipping reflectors of Hinz (1981) and Mutter (1985) typical of volcanic passive margins. They could build the prolongation of the zone of oceanward-dipping reflectors identified north of the Faeroe Islands by Smythe (1983) and Andersen (1988), and mark the northwestern edge of the RockallFaeroe microcontinent.

Another indication that the banks may be bordered to the northwest by oceanic crust can be found in the striking asymmetry of the banks on north-south sections (lines IF004 and IF006): the highest parts are located in the south and the flattened crests gently slope down towards the north (more probably to the northwest). It is also clear from line IF004 that north of Lousy Bank the sedimentary cover starts at a much lower level than south and east of this bank. If the ocean-continent transition really occurs northwest of the banks then the outer edges of the banks can be expected to have undergone enhanced subsidence by the thermal influence of the adjoining oceanic lithosphere.

Centrally in the basin between the banks the basement is displaced over $>150 \mathrm{~ms}$ by a single fault (both lines IF001/IF002 and IF006). This fault strikes approximately WNW-ESE, downthrowing the basement towards the southwest. Bill Bailey Bank is thus located on the upfaulted side. Neither the mode of faulting nor the origin can be established due to the limited data. The sediments overlying the fault display a large deiormational structure, which on the vertically exaggerated profiles shows up as a diapir, possibly originating in a movement of the fault.

The broad convex-upward curvature of the basement appearing southward of the fault (line IF006, Fig. 4) may be the expression of an underlying intrusion centre. The location of this structure with respect to the above-mentioned fault suggests that there is no genetic relation between the two structures.

\section{Sediment stratigraphy}

\section{Introduction}

The sediment distribution is confined by the location of the banks: the flattened crests bear nearly no sediment, whereas the basin between the banks is filled with $c .1200 \mathrm{~ms}$ of sediments.

Seismic stratigraphic interpretation allows identification of four regional unconformities in the basin between and southward of the banks. They result in the definition of five depositional units which are briefly described below. The most important results of the seismic stratigraphic analysis (mean thicknesses, unit bounding unconformities and their correlations, geometrical relationships of internal reflectors along these unconformities, etc.) are summarized in the seismic stratigraphic correlation table of Fig. 6. Correlation with the sediments northward of the banks was not possible in this study.

\section{Brief description of the depositional units}

The five depositional units that were recognized are successively described, from oldest to youngest. The following topics are discussed: (1) lower boundary; (2) upper boundary; (3) seismic facies; and (4) thickness variations.

\section{Depositional unit 1}

(1) The lower boundary of this unit, reflector $\mathrm{EE}$, coincides with the top of the Palaeocene flood basalts already described above. Internal reflectors show onlap against the flanks of both banks.

(2) The upper boundary of unit 1 is constituted by reflector $\mathrm{R} 4$, usually running parallel to the lava surface, except on line IF001/IF002 where R4 pinches out in westward direction against the crest of Lousy Bank. Internal reflectors are truncated by R4. Above the basement fault. observed on lines IF001/IF002 and IF006 it seems that R4 is interrupted by a large diapir piercing out of unit 1 . Eastward of this presumed diapir - which we label diapir B - reflector R4 is no longer recognized. A second, though minor diapir (diapir A) occurs more southward, above the basement updoming.

(3) Depositional unit 1 is characterized by a transparent seismic facies contrasting with the facies of the overlying units. Only sporadic internal reflectors of significant continuity can be recognized.

(4) The depositional unit reaches its maximum thickness of $c .650 \mathrm{~ms}$ where the basalt surface is at its greatest depth. The interval is apparently thicker in the eastern part of the basin, thins above the southern spur of Lousy Bank (200-300 m) and pinches out against the crest of this bank in the western part of profile IF001/ IF002. As will be discussed in the last section, these thickness variations indicate a different initial subsidence history for the two banks. The local thinning of the sediment interval above the presumed 
intrusion centre suggests that updoming of the lava surface started during the deposition of this oldest unit and after that went on for some time, as indicated by the rising of $\mathrm{R} 4$ along with the lava surface.

\section{Depositional unit 2}

(1) Reflector R4 marks the lower boundary of this unit. Stratal geometry is characterized by onlap of internal reflectors against R4, a relationship which is most prominently expressed around the basin margins.

(2) Upper boundary is a reflector provisionally labelled BB3. This reflector shows evidence of a slight erosive truncation of internal reflectors towards the basin edges, the only place where the boundary could be recognized. Except for the eastern flank of Lousy Bank - where the stratal geometry is parallel (see line IF001/ IF002) - BB3 everywhere wedges out against R4.

(3) The seismic facies of this second unit varies vertically as well as horizontally. In general it consists of discontinuous subparallel reflectors of medium to high amplitude and frequency. Where the unit reaches its maximum thickness the reflectivity decreases towards the lower boundary, so that the facies hardly differs from that of unit 1. In the zone southward of the banks depositional unit 2 (as well as the overlying units 3 and 4) is intersected by numerous subvertical faults with small offset (c. $10 \mathrm{~ms})$.

(4) The thickness of the sediment interval gradually increases from $200 \mathrm{~ms}$ in the south to almost $400 \mathrm{~ms}$ between the banks in the north. This trend is interrupted at the place of the above-mentioned diapiric structures, where the interval thins. This thinning cannot be fully ascribed to differential compaction and is probably due to the initiation of activity of these structures during the time interval corresponding to the deposition of unit 2 .

\section{Depositional unit 3}

(1) The internal reflectors of unit 3 show distinct onlap against reflector BB3, especially at the basin margins and around the diapirs. Remarkably this onlap (as observed on an E-W oriented section, line IF001/IF002) occurs in a westward direction, as opposed to the observed onlap in the underlying unit which occurs in an eastward direction. A change in direction of the sediment transport is therefore inferred to have taken place at the transition from unit 2 to unit 3.

(2) The upper boundary of depositional unit 3 is constituted by a reflector labelled BB4. The boundary truncates the internal reflectors but can pinch out laterally against BB3 or R4. Underlying depositional units are thus not truncated.

(3) The seismic facies of unit 3 does not differ markedly from that of the underlying and overlying units 2 and 4 . Locally it can become chaotic to reflection free.

(4) Unit 3 shows rather complex variations in thickness. The general trend is a thickening of the interval from $<100 \mathrm{~ms}$ in the north to $150-200 \mathrm{~ms}$ in the south, i.e. the opposite trend of the underlying unit. On line IF005 (Fig. 5) the interval (before wedging out in westward direction against reflector R4) displays a remarkable thickening of $c .50 \mathrm{~ms}$ which is produced by the upward bulging of all internal reflectors as well as of the upper boundary BB4. The reflections here exhibit higher amplitudes and frequencies than normal and lap out in downward direction against R4. This bulge might have its origin in deposition under current-controlled conditions.

\section{Depositional unit 4}

(1) The lower boundary of unit 4 is defined by reflector BB4. Stratal relationships with overlying internal reflectors are onlap (again best observed around the diapiric structures) and downlap (in westward direction) which was observed on line IF001/IF002.

(2) The upper boundary BB5 is characterized by a distinct erosional truncation. The reflector laps out laterally against $\mathbf{R 4}$, precluding truncation of underlying units. Also, BB5 is the sole boundary remaining subhorizontal over the whole area.

(3) The seismic facies is analogous to the facies of units 2 and 3: discontinuous subparallel reflectors of medium to high amplitude.

(4) The thickness of the sediment interval varies strongly between 100 and $200 \mathrm{~ms}$; in between the two diapirs the unit is only25-50 ms thick.

\section{Depositional unit 5}

(1) Reflector BB5 marks the lower boundary of unit 5. Laterally BB5 onlaps against R4. Internal reflectors run parallel to BB5.

(2) At the top unit 5 is bounded by the 

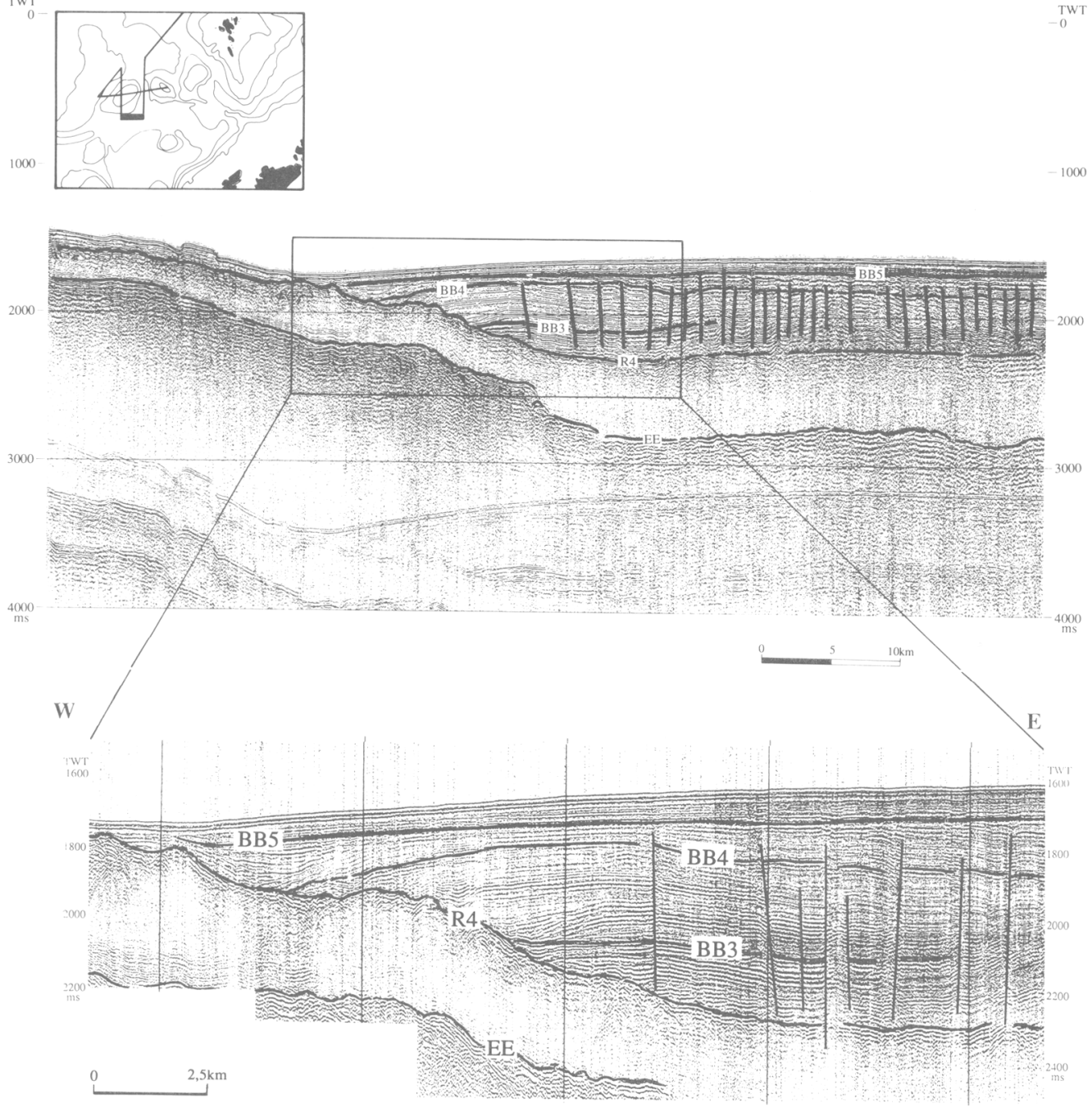

Fig. 5. Line IF005 (common offset plot). The blow-up is in fact a smaller-scale analogue monitor recording.

seafloor which generally parallels the internal reflectors.

(3) The seismic facies of unit 5 is fairly uniform: continuous, parallel and subhorizontal reflectors with high amplitude. The high amplitude reflections contrast to the facies of the underlying unit. Furthermore, the reflectors are no longer interrupted by subvertical faulting.

(4) The thickness of unit 5 is fairly constant and typically amounts to $100 \mathrm{~ms}$. The thickness decreases towards the basin margins and also above diapir $B$.
A concluding remark concerns the notable $\mathrm{E}-\mathrm{W}$ asymmetry of the basin between the banks (see line IF001/IF002). At the level of the lava surface the basin is still relatively symmetrical. Above this surface this is no longer the case. Unit 1 pinches out in a westward direction against Lousy Bank, while in the east the interval is almost parallel to the lava surface forming the flank of Bill Bailey Bank. For the overlying unit the situation is different: unit 2 is largely parallel to R4 above the flank of Lousy Bank and laps out against the same boundary eastward of diapir B. This geometry suggests 


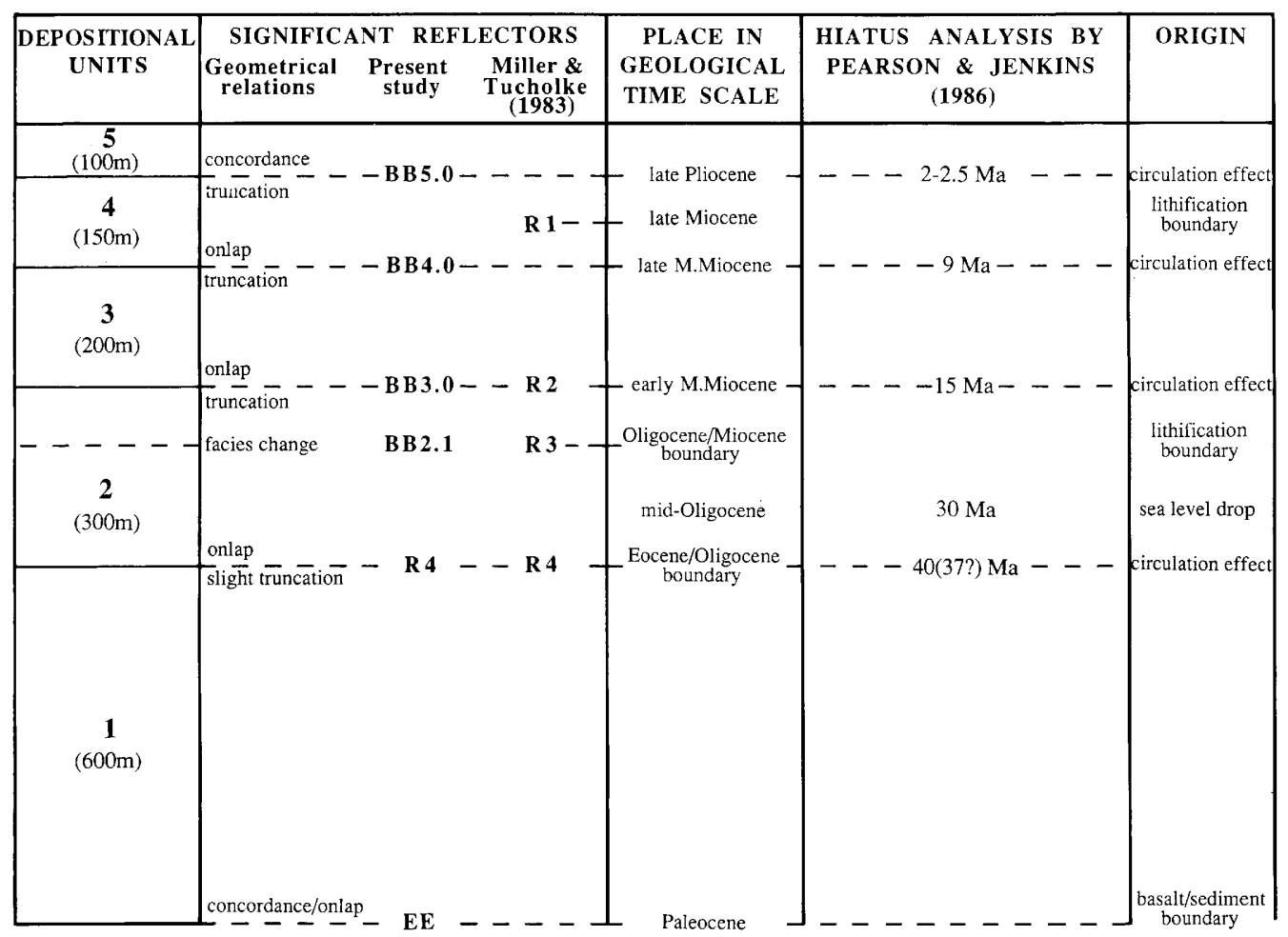

Fig. 6. Seismic stratigraphic correlation table for the area around Bill Bailey and Lousy Banks.

that Lousy Bank acted as sediment source during deposition of unit 2 . The transition from unit 2 to unit 3 is characterized by a change in direction of lapout: all overlying reflectors show onlap or downlap in a westward direction. This indicates a change in direction of the sediment transport from eastward to westward pointing towards Bill Bailey Bank as the new source for the deposited sediments.

\section{Correlations}

The lack of well control in the area under investigation makes correlation of the identified unconformities very difficult to establish. Moreover, the sequence stratigraphic approach, although successful for passive continental margins, does not seem to apply in this deep basinal area. Therefore, the correlations have to rely on results published by other authors. Earlier stratigraphic studies were published by, amongst others, Roberts (1975) and Miller \& Tucholke (1983) for the Rockall area, Roberts $e t$ al. (1983) for the area SW of the Faeroe Islands, and Wood et al. (1987) for the small area south of Ymir Ridge. Where possible, some of these results were drawn into our interpretation.

Additional useful information came from a hiatus analysis of all DSDP drillholes in the NE Atlantic by Pearson \& Jenkins (1986). They filtered out all hiatuses having a local tectonic origin and came to the following results, representing regional hiatuses which are expected to occur throughout most of the NE Atlantic: (1) two hiatuses in the Middle Eocene which are difficult to recognize outside the Rockall area; (2) a well-known hiatus at the Eocene-Oligocene boundary (c. 37 Ma); (3) a mid-Oligocene hiatus $(c .30 \mathrm{Ma})$ corresponding to the mid-Oligocene sea-level drop postulated by Vail et al. (1977); (4) a well-defined hiatus at the beginning of the Middle Miocene (15 Ma), probably corresponding to reflector R2 of Miller \& Tucholke (1983); (5) a widespread hiatus at the end of the Middle Miocene (9 Ma); (6) a hiatus at the end of the Pliocene $(2-2.5 \mathrm{Ma})$.

Our lowermost unconfornity is supposed here to correspond to the hiatus at the Eocene- 
Oligocene boundary. This unconformity marks the most prominent boundary. It is an outstanding onlap surface for overlying reflectors, and also corresponds to a striking facies change (e.g. line IF005; Fig. 5): below the seismic facies is largely transparent, while above the boundary numerous reflectors can be recognized. This characteristic suggests correlation with the well-known reflector R4 of the North Atlantic (Jones et al. 1970; Roberts 1975), which is supported by the analogy with a seismic line published by Roberts et al. (1983, fig. 3). This reflector was dated at the Eocene-Oligocene boundary (c. 37 Ma) (Laughton et al. 1972; Roberts 1975) and can be traced throughout the Rockall area (Roberts 1975; Miller \& Tucholke 1983), the eastern Reykjanes Basin (Ruddiman 1972), the Labrador Sea (Egloff \& Johnson 1975), and perhaps even in the Bay of Biscay (Montadert \& Roberts 1979).

The younger unconformities were provisionally labelled BB3-BB5, corresponding to the number of the overlying unit.

The uppermost unconformity, BB5, resembles the uppermost unconformity identified on seismic lines shot during the same survey on the northern flank of the Iceland-Faeroe Ridge. Interpretation parallel to the present study (Vanneste 1989) suggests that this reflector is of Pliocene age, as constrained by its depth at the intersection with DSDP drillhole 336. Although it was not recognized as a hiatus in drillhole 336 (Talwani et al. 1976), the reflector is likely to correlate with the hiatus at the end of the Pliocene common to most of the other DSDP drillholes in the Norwegian Sea.

As presented in the correlation table of Fig. 6, unconformities BB3 and BB4 are proposed to correlate with the hiatuses at the beginning and end of the middle Miocene, respectively. While the other correlations are relatively firm, the dating of these two middlemost reflectors is less reliable and is primarily based upon comparison with the hiatus analysis of Pearson \& Jenkins (1986), and upon the assumption (e.g. Miller \& Tucholke 1983) that regional deep sea hiatuses in this area have their origin in a change of the bottom-current regime rather than corresponding to the sea level - induced hiatuses of Vail et al. (1977). Because of its location near to the Iceland-Faeroe Ridge and the Faeroe-Shetland Channel, the area has certainly been influenced by strong changes of the water circulation regime.

Indeed, for two of the hiatuses a possible cause in a bottom current change is indicated in the literature. According to Miller \& Tucholke (1983) the hiatus corresponding to reflector R4 has its origin in the opening of Fram Strait [dated at c. $38 \mathrm{Ma}$ by Talwani \& Eldholm (1977)], which caused the first introduction of cold Arctic bottom water into the northern Atlantic. Berggren \& Schnitker (1983) argue that the final subsidence of the Iceland-Faeroe Ridge beneath sea level in the middle Miocene is responsible for the hiatus corresponding to $\mathrm{R} 2$ (which is probably equivalent to BB3).

\section{Sediment lithology}

Until now little has been known about the lithology of the deposits around Bill Bailey and Lousy Bank, mainly because scientific drilling has not yet taken place in this area. A tentative correlation with the results reported by Talwani et al. (1976) for DSDP hole 352 (located on the southern rise of the Iceland-Faeroe Ridge) suggests that in the upper unit the lithology may be dominated by sandy mud and mud mixed with coarse fragments; unit 2 , however, and by analogy units 3 and 4 (having a seismic facies analogous to that of unit 2), are not thought to correspond to the nannofossil ooze and chalk with cherty horizons of the Oligocene sediments in DSDP hole 352, but are believed to be rather terrigenous in origin. The transparent character and the observed diapirism in unit 1 point towards a homogeneous and fine-grained sediment texture.

\section{Sediment deformations}

A mere glance at the seismic lines tells us that the sediments have experienced several kinds of deformation. In a zone southward from the banks, depositional units 2 to 4 are affected by a pattern of minor subvertical faults (best observed on line IF005; Fig. 5). Displacement amounts only to $c$. $10 \mathrm{~ms}$. Due to the rather transparent character of the underlying unit, it is not clear whether these faults continue downward into this unit or not, but, because reflector R4 seems not to be broken up in exactly the same places as the overlying reflectors, it is suggested here that the faults are intraformational. Such intraformational faults have not previously been described in the area. Similar stratigraphically bounded faults were described by Henriet et al. (1988) in Ypresian clay deposits of the Southern Bight of the North Sea. This deformational style is inferred to be related to the compaction history of the sediment rather than to have resulted directly from regional tectonic stresses. A temporary state of increased pore pressure, like that occurring in a sealed clay 
body during burial, would produce these structures.

Another striking deformational structure has developed above the large basement fault (lines IF006 and IF001/IF002). In the first instance we interpreted this structure as a diapir (diapir B) piercing out of depositional unit 1. An interpretation which is based chiefly upon the pronounced updoming shape of the structure as displayed on our seismic profiles, as well as upon the fact that reflector R4 is absent beneath this structure. However, other features commonly accompanying diapiric structures, such as rim synclines, are apparently absent. Another 'diapir' observed further southwards is only a minor feature.

Apart from salt formations, which are not likely to be present in this area, diapirism is also known to occur in overpressurized fine-grained sediments. Bjørklund \& Kellogg (1972) report Upper Eocene clay drilled on similar diapiric structures observed on the Vøring Plateau, while Uenzelmann (1988) assumes diapirs in the Vøring Plateau area to have developed from underconsolidated terrigenous mud or diatom ooze.

Judging from the thickness variations of overlying sediment units, diapir B started its activity - probably as a result of a movement of the underlying basement fault in response to some regional tectonic stress - at some time during deposition of unit 2, i.e. in Oligocene or early Miocene times.

\section{Qualitative evaluation of the subsidence history}

One of the most remarkable features concerning the Palaeocene lavas is the pronounced relief presently exhibited by the top surface: the bank crests are now found at a water depth of 300 $500 \mathrm{~ms}$, rising $c .2200 \mathrm{~ms}$ above the basin floor. In surrounding areas also the present depth distribution of the lavas is very variable. They are at surface on the Faeroe Islands, at shallow depth and under a thin cover of sediments on the NW Scottish continental margin and on most of the bathymetric highs north of Rockall Trough (Rosemary Bank, the Wyville-Thomson and Ymir Ridges), but at considerable depth in the intervening basins where the basement is deeply buried below Tertiary sediments.

The voluminous extrusion of the flood basalts is generally accepted to have occurred predominantly subaerially, as indicated by: (1) the subaerial nature of the lava sequence on the Faeroe Islands (Noe-Nygaard \& Rasmussen
1968); (2) the penetration of DSDP hole 117 on the west side of Rockall Bank into pre-Upper Palaeocene subaerial basalt (Laughton et al. 1972); (3) the steep lava scarp forming the southward limit of the thick lavas (Roberts et al. 1983; Wood et al. 1987), interpreted by Wood $e t$ al. (1988) to mark the position of a palaeoshoreline where subaerial lava flows were cooled rapidly by the sea water and stopped flowing.

Two hypotheses can be considered concerning the origin of the present basement morphology. Roberts et al. (1983) suggested that the banks are the remnants of an original volcanic landform eroded subaerially. On the contrary, Wood et al. $(1987,1988)$ assume that all the lavas were extruded more or less horizontally, at or near sea level, implying radically different subsidence histories for areas lying only a small distance apart.

The subsidence history of the bank area is estimated here qualitatively from sediment distribution and stratal geometry patterns. In particular, the $\mathrm{E}-\mathrm{W}$ asymmetry of the basin between the banks at the level of the sediments indicates that the present basement topography did not exist as such immediately after outflow of the Palaeocene lavas.

Maybe a less pronounced basement topography was present already before the lava top subsided below sea level. Arguments for this are slight onlap of pre-R4 sediments against the flank of Bill Bailey Bank (line IF006) and the flattened appearance of the bank crests, ascribed to subaerial erosion (Roberts et al. 1983).

The initial subsidence of the basalt surface is thought to have occurred more or less uniformly. This is indicated by the fact that reflector $\mathrm{R} 4$ remains almost parallel to the basalt surface, with the exception of the eastern flank of Lousy Bank where R4 laps out against the bank crest. Since R4 is an outstanding onlap surface for all overlying reflectors, it is suggested that subsidence became non-uniform after generation of this surface, so that the organization into banks and basins became more prominent. Instead of explaining the observed stratal patterns by a shift from spatially uniform to differential subsidence, one could equally argue for a dramatic decrease of the sediment input after erosion of R4 under a steady but differential subsidence regime. This is, however, not supported by the accumulation rates inferred from the age correlations presented here for the unit bounding unconformities.

The onlap of R4 against the crest of Lousy Bank implies that differential subsidence started firstly around the eastern edge of Lousy Bank (still in Eocene times) and only later around Bill 


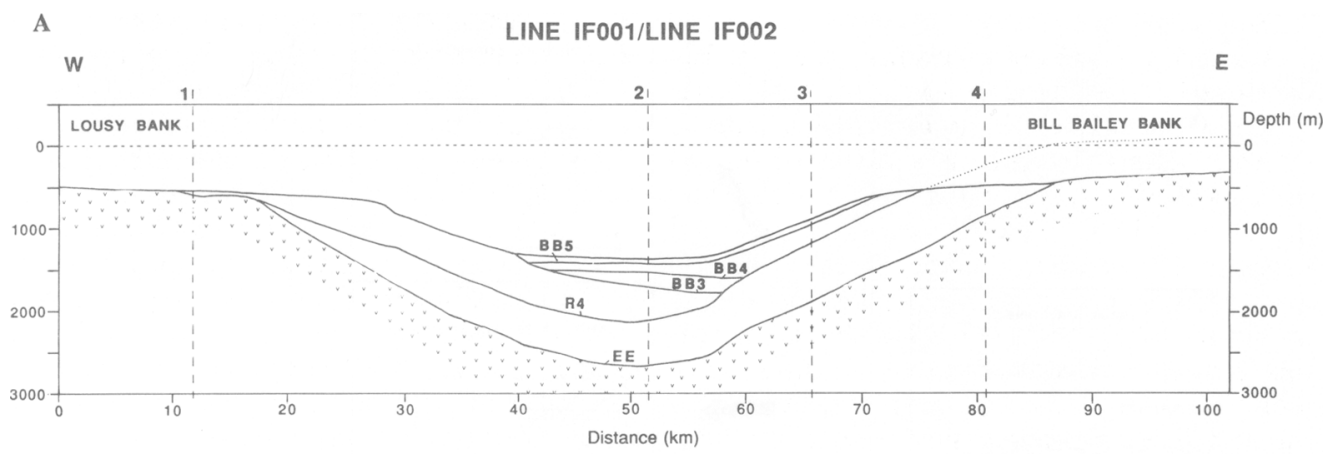

B

TOTAL TECTONIC SUBSIDENCE CURVES

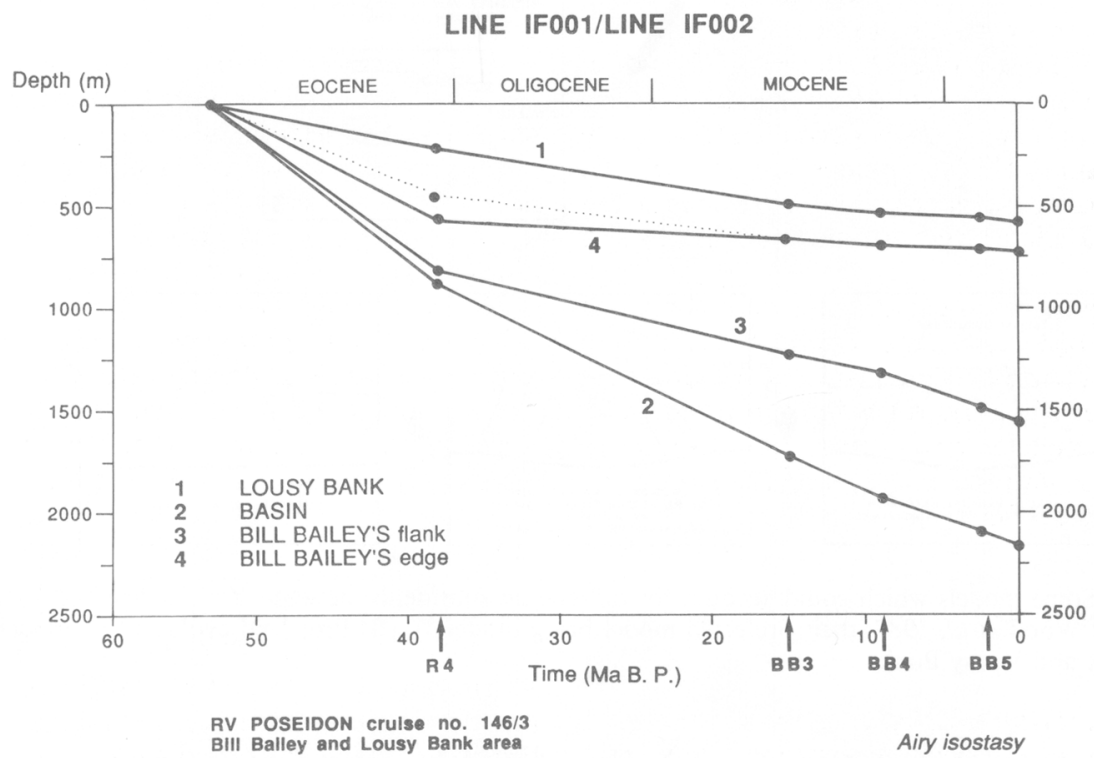

Fig. 7. (A) Simplified line drawing of profile IF001/IF002. 1-4 indicate the positions of four points along the profile for which the schematic total subsidence curves are shown in (B). Palaeobathymetry and erosion cannot be integrated at present.

Bailey Bank and in the zone southward of the banks. Lousy Bank, subsiding more slowly, was thus isolated first. This suggestion - though apparently in contradiction with the present bathymetry (Bill Bailey Bank surmounts Lousy Bank by $200-300 \mathrm{~m}$ ) - is supported by the identifica-tion of Lousy Bank as the most important sediment source during deposition of unit 2 , as interpreted from the observed geometry of this depositional unit. At the EoceneOligocene boundary Bill Bailey Bank also began differential subsidence while the rest of the basalt surface kept on subsiding at the same pace. This is illustrated by the idealized total tectonic subsidence curves for four different points along line IF001/IF002 in Fig. 7.

Stratal patterns further suggest that between deposition of units 2 and 3 (i.e. in early Miocene times) a shift took place in the direction of the sediment transport, and that Bill Bailey Bank at that time became the main source for the deposited sediments. This complication in the subsidence history could have been caused by the generation of the above described large basement fault, upthrowing Bill Bailey Bank. This fault is thought to have started its activity 
A
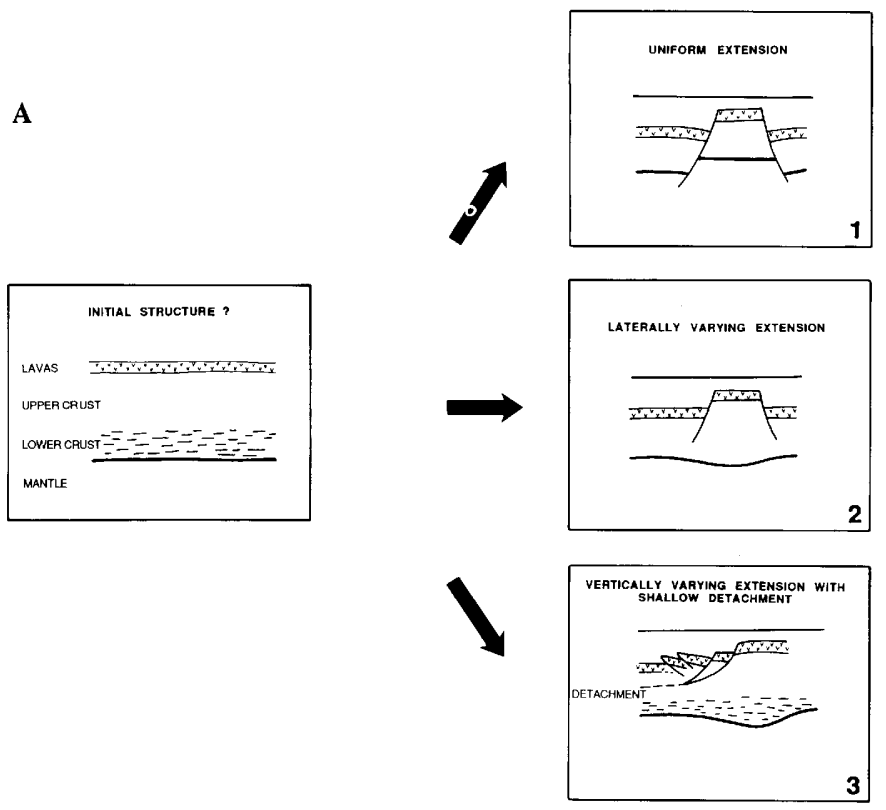

B
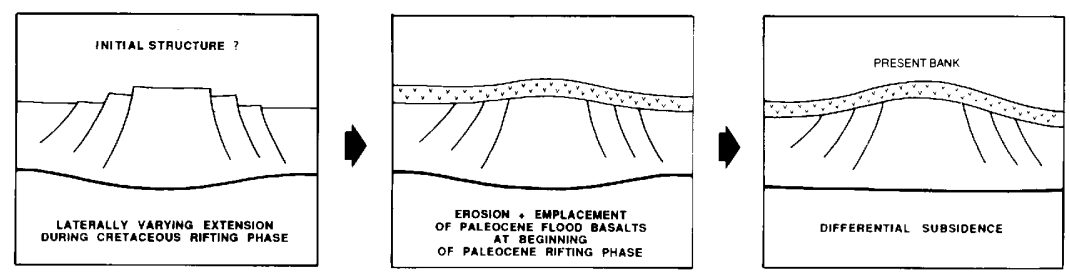

Fig. 8. (A) Some models which could account for differential subsidence between Ymir Ridge and its southern basin (from Wood et al. 1987; their preferred model being model 3). (B) Proposed evolutionary model for Bill Bailey Bank and Lousy Bank.

at some time during deposition of unit 2 . The present bathymetry is also in favour of this hypothesis. It is not yet clear what mechanism caused these movements, but a phase of widespread compression has been inferred by Boldreel \& Andersen (1993) for the NW margin of the Rockall-Faeroe area in the middle or late Miocene.

Two aspects of this subsidence history remain to be solved: why was the subsidence differential and why did differential subsidence become important only after the Eocene-Oligocene boundary?

A possible explanation for the differential aspect of the subsidence could be the presence of magma chambers beneath the zones presently standing out in relief. However, apart from the Faeroe Bank Centre - identified from magnetic anomalies by Dobinson (1970), but not con- firmed by gravity measurements according to Andersen \& Boldreel (pers. comm.) - so far no intrusion centres have been reported beneath the banks. Extensional models have been proposed for the differential subsidence of Ymir Ridge and its southern basin by Wood et al. (1987) (Fig. 8A, their preferred model being model 3), but these models all imply large-scale faulting through the entire lava pile, which we did not observe in this area. But we can consider a slight modification of the model of laterally varying extension by assuming the presence of extensional faults in the underlying continental crust, which could be affected by the two extensional episodes preceding emplacement of the lava pile. The present bank zones would then represent more stable fragments, stretched to a lesser extent than the surrounding areas (Fig. 8B). Subsequent thermal disturbances, such as the 


\section{TERTIARY SUBSIDENCE CURVES FOR LAVA TOPS}

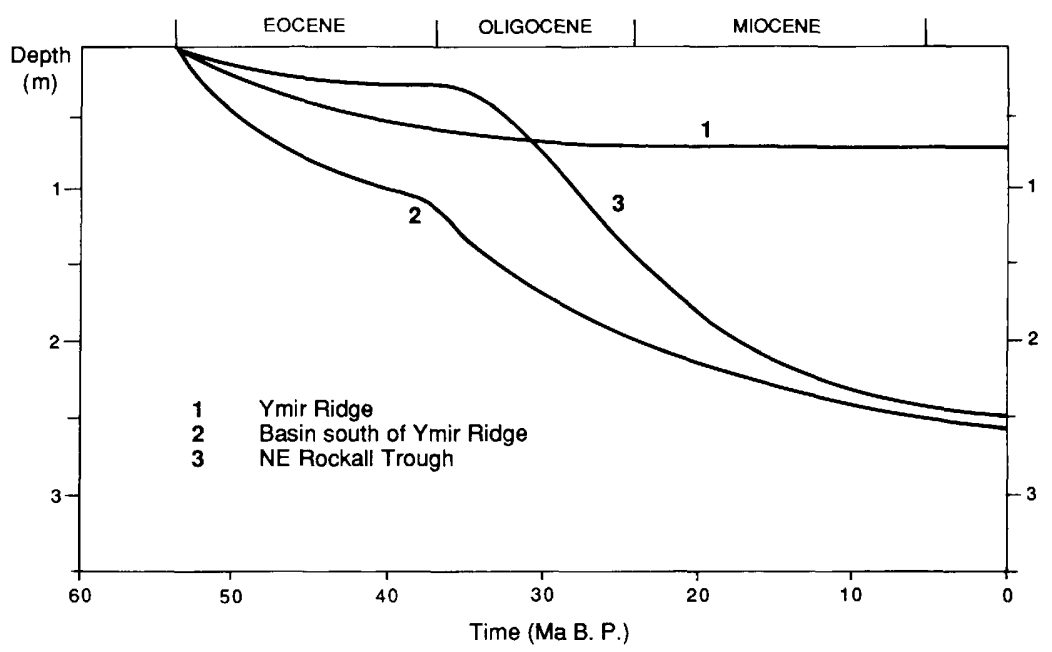

Fig. 9. Compilation of Tertiary subsidence curves for the lava tops of Ymir Ridge and the basin south of Ymir Ridge (from Wood et al. 1987), and of the NE Rockall Trough (from Wood et al. 1988).

massive extrusion of hot volcanics at the end of the Palaeocene, could have reactivated the subsidence, resulting in little subsidence for the bank areas and enhanced subsidence in the intervening areas. It should be stressed, however, that this model is a tentative one, and has not yet been constrained by deep geophysical observations or calculations.

The event that caused the shift from uniform to differential subsidence at the Eocene-Oligocene boundary is not well documented either. However, it is not an isolated observation. For the basin southward of Ymir Ridge, Wood et al. (1987) inferred a subsidence in two distinct phases as well. Their subsidence curves (Fig. 9) show a rapid increase in the subsidence rate in early Oligocene times. Together with the observation by Roberts (1975) of post-Early Oligocene subsidence events in the HattonRockall Basin and in the Porcupine Seabight, this strongly indicates that a tectonic event of regional importance occurred around this time. The cessation of spreading in the Labrador Sea was such an event that had major complications for the evolution of the northern North Atlantic: it resulted in the development of complementary fan-shaped spreading along two axes in the Greenland-Norwegian Sea, representing a reorientation of the direction of spreading between Greenland and Eurasia (Nunns 1983). This complex Oligocene spreading geometry is held to be responsible for compression in the Wyville-Thomson area (Boldreel \& Andersen 1993), and may also be a likely cause for the observed events.

\section{Conclusions}

(1) The present banks are the expression of the morphology of the underlying volcanic substratum. On the flattened bank crests basaltic rocks are near surface, only covered by a thin veneer of sediments, while in the intervening basin the volcanic basement reaches a depth of more than $2000 \mathrm{~ms}$ and is buried below more than $1000 \mathrm{~ms}$ of sediments. The pronounced basement relief appears not to be fault controlled. (2) Intrabasement divergent reflectors beneath the northern and western flanks of Lousy Bank, and beneath the northern flank of Bill Bailey Bank are thought to build the prolongation of the zone of oceanward dipping reflectors identified north of the Faeroe Islands, and mark the northwestern edge of the Rockall-Faeroe microcontinent. The location of the ocean-continent transition near the northwest edges of the banks is also supported by the asymmetrical shapes of the banks as revealed on N-S sections. (3) Four unconformities were identified in the basin between and southward of the banks where sediment accumulation is confined. The lower reflector marks the most prominent boundary, 
and is suggested to correspond to $\mathrm{R} 4$, a reflector which is known throughout large parts of the North Atlantic and has been dated at the Eocene-Oligocene boundary. The other unconformities were provisionally labelled BB3-BB5. They are proposed to correlate with hiatuses at the beginning (BB3) and at the end (BB4) of the middle Miccene, and at the end of the Pliocene (BB5). They are thought to have their origin for the main part in changes of the bottom-current regime. (4) The sediments are affected by several kinds of deformation, including a pattern of intraformational faults with small offset and a diapir-like structure. Both deformational styles are probably related to an increase of the pore pressure in fine-grained sediments, but resulting from differen $i$ causes. The overpressuring seems to be related to the compactional history of the sediments in the case of the intraformational faults; in the other case it may have been induced by the movement of an underlying basement fault. (5) It is inferred from the stratal geometry that the investigated banks are not the eroded remnants of an originai volcanic landscape, but have been formed by differential subsidence. The initial subsidence of the basalt surface is thought to have occurred more or less uniformly. The pronounced onlap of overlying reflectors against R4 suggests that subsidence became non-uniform after generation of this surface, at the Eocene-Oligocene boundary. Around Lousy Bank differential subsidence started somewhat eariier. The mechanisms responsible for these observations are still poorly understood.

Data presented here were collected during cruise No $146 / 3$ of R.V. Poseidon. We would like to thank the captain and crew of R.V. Poseidon for their assistance during the data gathering. The survey was carried out within the project MFG 00664, which was funded by the German Ministry of Technology and Research (BMFT). The Belgian participation into the research project was funded by the Fund for Joint Basic Research (FKFO). We wish to thank M. De Batist, as well as M. S. Andersen and L. O. Boldreel from the Danish Geological Survey for kindly reviewing the manuscript and for helpful suggestions. One of the authors (K.V.) is Research Assistant at the Belgian National Fund for Scientific Research (N.F.W.O.).

\section{References}

Andersen, M. S. 1988. Late Cretaceous and early Tertiary extension and volcanism around the Faeroe Islands. Iin: MORTON, A. C. \& PARSON, L. M. (eds) Early Tertiary Volcanism and the Opening of the NE Atlantic. Geological Society, London, Special Publication, 39, 115-122.

Berggren, W. A. \& Schnitker, D. 1983. Cenozoic marine environments in the North Atlantic and Norwegian-Greenland Sea. In: BotT, M. H. P., Saxov, S., Talwani, M. \& Thiede, J. (eds) Structure and Development of the GreenlandScotland Ridge. Plenum Press, New York, 495548.

BjørKlund, K. R. \& KellogG, D. 1972. Five new Eocene Radiolarian species from the Norwegian Sea. Micropaleontology, 18, 386-396.

Boldreel, L. O. \& ANDERSEN, M. S. 1993. Late Paleocene to Miocene compression in the FaeroeRockall area. In: PARKER, J. R. (ed.) The Petroleum Geology of NW Europe: Proceedings of the 4th Conference. The Geological Society, London, 1025-1034.

Bott, M. H. P., Browitt, C. W. A. \& Stacey, A. P. 1971. The deep structure of the Iceland-Faeroes Ridge. Marine Geophysical Researches, 1, 328351 .

, Sunderland, J., Smith, P. J., Casten, U. \& Saxov, S. 1974. Evidence for continental crust beneath the Faeroe Islands. Nature, 248, 202-204.

CAsten, U. 1973. The crust beneath the Faeroe Islands. Nature, 241, 83-84.

Dobinson, A. 1970. 1. The development of a marine seismic recording system. 2. A magnetic survey of the Faeroe Bank. PhD thesis, University of Durham, UK.

Egloff, J. \& Johnson, G. L. 1975. Morphology and structure of the southern Labrador Sea. Canadian Journal of Earth Sciences, 12, 2111-2133.

Hald, N. \& WaAgSTEIN, R. 1983. Silicic basalts from the Faeroe Islands: evidence of crustal contamination. In: BotT, M. H. P., SAXov, S., TAlwani, M. \& Thiede, J. (eds) Structure and Development of the Greenland-Scotland Ridge. Plenum Press, New York, 343-349.

Henriet, J.-P, De Batist, M., Van Vaerenbergh, W. \& Verschuren, M. 1988. Seismic facies and clay tectonic features of the Ypresian clay in the southern North Sea. Bulletin van de Belgische Vereniging voor Geologie, 97-3/4, 457-472.

Hinz, K. 1981. A hypothesis on terrestrial catastrophes. Wedges of very thick oceanward dipping layers beneath passive continental margins - their origin and paleoenvironmental significance. Geologisches Jahrbuch, Reihe E: Geophysik, 22, 1741.

Jones, E. J., Ewing, M., Ewing, J. I. \& EitTreim, S L. 1970. Influences of Norwegian Sea overflow water on sedimentation in the northern North Atlantic and Labrador Sea. Journal of Geophysical Research, 75, 1655-1680.

LAughton, A. S., Berggren, W. A., ET AL. 1972. Initial Reports of the Deep Sea Drilling Project. 12, US Government Printing Office, Washington DC.

Miller, K. G. \& Tucholke, B. E. 1983. Development of Cenozoic abyssal circulation south of the Greenland-Scotland Ridge. In: BoTT, M. H. P., Saxov, S., Talwani, M. \& Thiede, J. (eds) Structure and Development of the GreenlandScotland Ridge. Plenum Press, New York, 549589.

Montadert, L. \& Roberts, D. G. (eds) 1979. Initial 
Reports of the Deep Sea Drilling Project, 48, US Government Printing Office, Washington DC.

MutTER, J. C. 1985. Seaward dipping reflectors and the continent-ocean boundary at passive continental margins. In: HuSEBYE, E. S., JOHNSON, G. L. \& KRISTOFFERSEN, Y. (eds) Geophysics of the Polar Regions. Tectonophysics, 114, 117-131.

Noe-Nygaard, A. \& Rasmussen, J. 1968. Petrology of a 3000 metre sequence of basaltic lavas in the Faeroe Islands. Lithos, 1, 268-304.

NunNs, A. G. 1983. Plate tectonic evolution of the Greenland-Scotland Ridge and surrounding regions. In: BotT, M. H. P., SaXov, S., TAlwaNI, M. \& THIEDE, J. (eds) Structure and Development of the Greenland-Scotland Ridge. Plenum Press, New York, 11-30.

PeARSON, I. \& Jenkins, D. G. 1986. Unconformities in the Cenozoic of the North-East Atlantic. In: Summerhayes, C. P. \& Shackleton, N. J. (eds) North Atlantic Palaeoceanography. Geological Society of London, Special Publication, 21, 79-86.

RoBERTS, D. G. 1975. Marine geology of the Rockall Plateau and Trough. Philosophical Transactions of the Royal Society of London, 278A, 447-509.

, BotT, M. H. P. \& URUSKi C. 1983. Structure and origin of the Wyville-Thomson Ridge. In: BotT, M. H. P., Saxov, S., Talwani, M. \& THIEDE, J. (eds) Structure and Development of the Greenland-Scotland Ridge. Plenum Press, New York, 133-158.

RudDIMAN, W. F. 1972. Sediment redestribution on the Reykjanes Ridge: seismic evidence. Geological Society of America Bulletin, 86, 2039-2062.

SMYTHE, D. K. 1983. Faeroe-Shetland Escarpment and continental margin north of the Faeroes. In: BotT, M. H. P., SAXov, S., Talwani, M. \& THIEDE, J. (eds) Structure and Development of the Greenland-Scotland Ridge. Plenum Press, New York, 109-119.

Talwani, M. \& Eldholm, G. 1977. Evolution of the
Norwegian-Greenland Sea. Geological Society of America Bulletin, 88, 969-999.

\& UDINTSEV, G., ET AL. 1976. Initial Reports of the Deep Sea Drilling Project, 38, US Government Printing Office, Washington DC.

UenzelmanN, G. 1988. Sedimente des südlichen Äußeren Vöring Plateaus - eine hochauflösende reflexionsseismische Untersuchung. Berichte aus dem Sonderforschungsbereich 313: Sedimentation im Europäischen Nordmeer, nr. 12, ChristianAlbrechts Universität zu Kiel.

VAIl, P. R., Mrtchum, R. M., Jr \& Thompson, S., III 1977. Seismic stratigraphy and global changes of sea level. Part 4: Global cycles of relative changes of sea level. In: PAYTon, C. E. (ed.) Seismic Stratigraphy - Applications to Hydrocarbon Exploration. The Association of American Petroleum Geologists Memoir, 26, Tulsa pp. 83-97.

VANNESTE, K. 1989. Seismische stratigrafie en geodynamische evolutie van de Ijsland-Faeroe en Kolbeinsey Ruggen. Unpublished Lic. thesis, State University of Gent.

WAAGSTEIN, R. 1988. Structure, composition and age of the Faeroe basalt plateau. In: MORTON, A. C. \& PARson, L. M. (eds) Early Tertiary Volcanism and the Opening of the NE Atlantic. Geological Society, London, Special Publication, 39, 225238.

Wood, M. V., Hall, J. \& Doody, J. J. 1988. Distribution of early Tertiary lavas in the NE Rockall Trough. In: Morton, A. C. \& PArson, L. M. (eds) Early Tertiary Volcanism and the Opening of the NE Atlantic. Geological Society, London, Special Publication, 39, 283-292.

\& VAN Hoorn, B. 1987. PostMesozoic differential subsidence in the north-east Rockall Trough related to volcanicity and sedimentation. In: BrooKs J. \& GlenNIE, K. (eds) Petroleum Geology of North West Europe, 2, Graham \& Trotman, London, 677-685. 